\title{
MORPHOAGRONOMIC AND SENSORY PERFORMANCE OF COFFEE CULTIVARS IN INITIAL STAGE OF DEVELOPMENT IN CERRADO MINEIRO
}

\author{
Dyanna Rangel Pereira ${ }^{1}$, João Augusto Rodrigues de Aguiar ${ }^{2}$, Denis Henrique Silva Nadaleti ${ }^{3}$, \\ Larissa de Oliveira Fassio ${ }^{4}$, João Paulo Felicori Carvalho ${ }^{5}$, Samuel Pereira de Carvalho ${ }^{6}$, \\ Gladyston Rodrigues Carvalho ${ }^{7}$
}

(Received: March 22 2019; accepted: May 14, 2019)

\begin{abstract}
Despite the great diversity of available Arabica coffee cultivars it is observed that, even when presenting different phenotypes of interest, new cultivars are adopted at a slow pace by coffee growers. One possible reason may be the lack of information on the performance of these genotypes in different regions and culture conditions. The aim this work was to verify the performance of twelve coffee cultivars in relation to morphoagronomic characteristics at initial stage of development, as well as the beans quality, in a condition of typical cultivation of the Cerrado. The trial was carried out in the municipality of Monte Carmelo - MG, in randomized block design, with four replicates. Morphoagronomic characteristics were evaluated 15 months after the implantation of the crop. The productivity and, subsequently, the quality of the beans, were evaluated at 18 months. Statistical analyzes were performed using the Genes software. The data were submitted to analysis of variance. The F test was used to determine the significance of treatments. The means were grouped by the Scott-Knott test (1974) at 5\% probability and the experimental precision was verified by the estimation of the experimental variation coefficient (CV) and the selective accuracy. The sensory attributes were evaluated in a radar diagram, called "Sensogram". Genetic variability was observed among cultivars for the vegetative characters. The cultivars Catuaí Vermelho IAC 144 and MGS Aranãs stood out as more productive, with a high percentage of sieve 16 and above and low percentage of grain type mocha. All the cultivars stood out as special, with emphasis on the cultivar Bourbon Amarelo IAC J10 in the wet processing and Catuaí Vermelho IAC 144 in the natural processing.
\end{abstract}

Index terms: Coffea arabica L., coffee breeding, vegetative growth, coffee quality.

\section{DESEMPENHO MORFOAGRONÔMICO E SENSORIAL DE CULTIVARES DE CAFÉ EM ESTÁDIO INICIAL DE DESENVOLVIMENTO NA REGIÃO DO CERRADO MINEIRO}

RESUMO: Apesar da grande diversidade de cultivares de café arábica disponíveis, observa-se que, mesmo apresentando diversos fenótipos de interesse, novas cultivares vêm sendo adotadas em ritmo lento pelos cafeicultores. Uma possível razão pode ser a falta de informação sobre o desempenho desses genótipos nas diferentes regiões e condições de cultivo. Objetivou-se com este trabalho verificar, em condição de cultivo típica do cerrado mineiro, o desempenho de doze cultivares de café quanto aos caracteres morfoagronômicos em estádio inicial de desenvolvimento, bem como a qualidade de grãos. O experimento foi realizado no município de Monte Carmelo - MG, em delineamento de blocos casualizados, com quatro repetições. Os caracteres morfoagronômicos foram avaliados 15 meses após a implantação da lavoura. A produtividade e, posteriormente, a qualidade dos grãos, foram avaliados aos 18 meses. As análises estatísticas foram realizadas com auxílio do software Genes. Os dados foram submetidos a análises de variância e utilizou-se o teste F para determinar a significância dos tratamentos. As médias foram agrupadas pelo teste de Scott-Knott (1974) a 5\% de probabilidade e a precisão experimental foi aferida pela estimativa do coeficiente de variação experimental (CV) e da acurácia seletiva. Os atributos sensoriais foram avaliados em um diagrama de radar, denominado "Sensograma". Constatou-se variabilidade genética entre as cultivares para os caracteres vegetativos. As cultivares Catuaí Vermelho IAC 144 e MGS Aranãs destacaram-se como mais produtivas, com alta porcentagem de peneira 16 e acima e baixa porcentagem de grãos tipos moca. Todas as cultivares destacaram-se como especiais, com destaque para a cultivar Bourbon Amarelo IAC J10 no processamento cereja descascado e Catuaí Vermelho IAC 144 no processamento natural.

Termos para indexação: Coffea arabica L., melhoramento do cafeeiro, crescimento vegetativo; qualidade do café.

\section{INTRODUCTION}

According to National Register of Cultivars there are currently 132 cultivars of Arabica coffee available to farmers in the
Brazilian market (MAPA, 2019). However, in spite of this great availability and variability, it is estimated that cultivars Mundo Novo and Catuaí occupy more than $85 \%$ of the national coffee

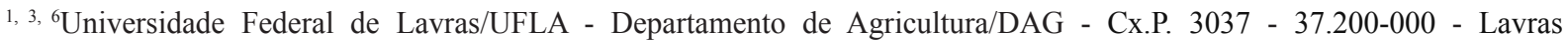
MG dyannarangel@hotmail.com,denishenriquesilva@yahoo.com.br, samuelpc@ufla.br

${ }^{2}$ Kuhlmann Monitoramento Agrícola LTDA - R. Jaguaraiva, 49 - 83.327-070 - Pinhais - PR - joaoaugustoagro@gmail.com ${ }^{4}$ Federação dos Cafeicultores do Cerrado - R. Rio Branco, 231 - 38.740-000 - Patrocínio -MG - larissafassio@yahoo.com.br ${ }^{5}$ Fundação de Desenvolvimento do Cerrado Mineiro/FUNDACCER - R. Rio Branco, 231 - 38.740-000 -Patrocínio - MG joao.paulo@cerradomineiro.org

${ }_{7}^{7}$ Empresa de Pesquisa Agropecuária de Minas Gerais/EPAMIG - Campus UFLA - Cx.P. 176 - 37.200-000 - Lavras - MG carvalho@epamig.ufla.br
} 
park (CONSÓRCIO PESQUISA CAFÉ, 2012; REVISTA CAFEICULTURA, 2015). Although these cultivars present high productive potential and interest morphoagronomic characteristics to coffee grower it is observed that the new cultivars are adopted at a very slow pace. One possible reason for this behavior is the lack of information on the agronomic performance of these cultivars in different cultivation sites and conditions, making it impossible to recommend them on a technical basis in the different coffee regions of the country (CARVALHO et al., 2010; CARVALHO et al., 2012).

Considering the great environmental variability and conditions of coffee cultivation in Brazil, it is known that the success of the crop depends on the adaptability of the genotypes to the different coffee regions (MOURA et al., 2000). The maximum productive potential of a cultivar is expressed only when it is subjected to optimal growing conditions for this genetic material. Thus, the adaptation of genotypes to specific environments can make the difference between a good and an excellent cultivar (CARGNIN et al., 2006).

Several research institutions have carried out studies aiming at the recommendation of cultivars adapted to the different coffee producing regions of the country, considering the possibility of genotypes by environments interaction and seeking, in addition to the greater productivity, other characteristics of interest such as tolerance to water deficit, resistance to pests and diseases and better sensory quality, in other words, favorable phenotypes for several characteristics that lead to a higher productivity, quality and sustainability of the crop (BOTELHO et al, 2010; CARVALHO et al., 2010; MARTINEZ et al., 2007; MOURA et al.,2000; RIBEIRO et al., 2018).

For many years, grain yield has been the main criterion for selection of coffee cultivars. However, it is possible to use other strategies to maximize the gains with the selection, to minimize the time to obtain new cultivars and to reduce costs in the breeding programs (CARVALHO et al., 2010; TEIXEIRA, et al., 2013).

Several authors relate agronomic characteristics to the productive potential of coffee genotypes. So, the early evaluation of morphoagronomic characters during the vegetative development of coffee became of the most efficient way to advance the cultivars development. Thus, discrimination of the most promising genotypes in the early stages of breeding provides the breeder more suitable criteria for selection, saving time and resources (CARVALHO et al., 2010; CRUZ; REGAZZI; CARNEIRO, 2004; SEVERINO et al., 2002).

There are several examples of correlation between morphoagronomic characteristics and productivity in coffee culture. Freitas et al. (2007) found success in the identification of superior genotypes performing early selection based on the length of plagiotropic branches at 12 months of plant age. In low-growing cultivars, stem diameter can be used as a juvenile pre-selection criterion for photosynthetic productivity. Nacif (1997) verified, from 2.5 years, that the productivity correlates positively with the diameter of the stem base and negatively with the height of the plant and with the maximum diameter of the crown, and the selection in juvenile stages of the plant is a alternative to the traditional selection criterion based on grain yield. Severino et al. (2002), when evaluating data accumulated during the first three years of production, found an association between vegetative vigor and grain production. Teixeira, et al. (2013) found that the length of the first plagiotropic branch, vigor, stem diameter and number of nodes of the first plagiotropic branch are the variables of major importance and considered sufficient for the distinction of genotypes in Arabica coffee, even at juvenile stage. When evaluating the direct and indirect effects of different morphological characters on grain production, obtained from the correlation between them, Teixeira et al. (2012) concluded that the length of the first plagiotropic branch and the vegetative vigor, at 12 months of age, can be used in the early selection of grain production in Arabica coffee.

In the Cerrado Mineiro region, where coffee cultivation was established in the 1970s, climatic and topographic factors present high compatibility with the crop (FERNANDES et al., 2012; ORTEGA, JESUS, 2009; ORTEGA, JESUS, 2011). After the development and technification of coffee cultivation allied to research to obtain cultivars adapted to local conditions, this region has become one of the most important producing regions of arabica coffee in the country, corresponding to $15 \%$ of Arabica coffee produced in Brazil (CONAB, 2018).

In addition, the influence on the beans quality of characteristics such as climate, soil, relief, temperature and production practices, 
gave the producers of the Cerrado the first Denomination of Origin (DO) for coffee in Brazil, boosting the production of specialty coffees in the region, besides adding value and guaranteeing product traceability (FERNANDES et al., 2012; ORTEGA, JESUS, 2009; ORTEGA, JESUS, 2011; SAES, JAYO, 1997).

In view of the above, the objective in this study was to verify the performance of twelve coffee cultivars for the morphagogonomic traits at the initial stage of development, as well as for beans quality, in a condition of typical cultivation of the Cerrado Mineiro region.

\section{MATERIAL AND METHODS}

The experiment was evaluated in the agricultural year of 2017/18 at Fazenda Castelhana, in the municipality of Monte Carmelo, in the mesoregion of the Triângulo Mineiro/Alto Paranaíba in the State of Minas Gerais - Brazil. The municipality is located at 890 meters of altitude, at $18^{\circ} 44^{\prime} 07.6^{\prime \prime}$ south latitude and $47^{\circ} 27^{\prime} 03.9^{\prime \prime}$ west longitude, with average temperature of $22.2{ }^{\circ} \mathrm{C}$ and precipitation of $1260 \mathrm{~mm}$ in the agricultural year of 2017/18 (COOXUPÉ, 2019).

Twelve cultivars of Arabica coffee (Table 1) implanted in the area in the agricultural year of 2016/17 were evaluated in a randomized complete block design (DBC) with four replicates, totaling 48 experimental plots. Each plot was composed by six plants, spaced 4.0 x 0.5 meters.

Fifteen months after planting in the field, the following characteristics were evaluated: plant height, measured in centimeters from the soil level to the apical bud of the orthotropic branch; number of plagiotropic branches, by means of direct counting in the plants; diameter of the crown, measured in centimeters and adopting the total length of the first two plagiotropic branches from the base of the plant; diameter of the stem, measured in millimeters, at a height of $10 \mathrm{~cm}$ from the ground, using a digital caliper; vegetative vigor, measured on an arbitrary scale of 1 to 10 , where 1 refers to the less vigorous plants and 10 to extremely vigorous, leafy plants with high growth of productive branches (CARVALHO.; MONACO; FAZUOLI, 1979). At the time of harvest, productivity was measured in liters of coffee harvested per plot, with subsequent conversion to $60 \mathrm{~kg}$ bags of coffee processed ha ${ }^{-1}$ considering an average yield of 500 liters of coffee harvested per processed bag. The harvest was performed 18 months after field planting in field.
After harvesting, 14 liters of mature coffee were taken per plot, of which seven liters were wet processed, obtaining pulped natural coffee. The other seven liters were dry processed (natural). The samples were submitted to drying in suspended terraces until reaching $11 \%$ water content and were stored for 30 days in a cold chamber at approximately $18^{\circ} \mathrm{C}$.

Subsequently, the samples were processed and submitted to the following evaluations: aspect of the raw grains, according to the methodology proposed by Nadaleti et al. (2018), with a score of 1 to 5 , where 1 corresponds to grains with uneven appearance, discrepant color, and adhered espermoderm and 5 corresponds to grains with uniform appearance, intense bluish-green without adhered espermoderm; sensory analysis of the coffees by three Q-graders judges, calibrated according to the protocol of the Association of Special Coffees (SCA).

Statistical analyzes were performed using the Genes software (CRUZ, 2013). The data were submitted to analysis of variance and the $\mathrm{F}$ test was used to determine the significance of the treatments. The means were grouped by the Scott-Knott test (1974) at 5\% probability and the experimental precision was verified by the estimation of the experimental variation coefficient (CV) and the selective accuracy.

The sensory attributes of the coffees were evaluated in a radar diagram (graph scale), called "Sensogram", with the average score of these attributes.

\section{RESULTS AND DISCUSSION}

High experimental precision was found for the two evaluation strategies. Estimates of selective accuracy were high magnitude ranging from 72.55\% (Aspect NC) To 99.56 (Prod). Selective accuracy values above $70 \%$ indicate high experimental accuracy. CV values varied from $0.50 \%$ (Sensory PNC) to $19.93 \%$ (Mocha), which also suggests good experimental precision (Table 2). According to Resende and Duarte (2007), the selective accuracy does not depend on the magnitude of the mean, such as CV. Therefore, it provides greater safety in the use of phenotypic expression as an indicator of genotype variation.

The evaluated traits, except for the Aspect NC presented significant difference between cultivars (Table 2 ) by the $\mathrm{F}$ test at $5 \%$ probability. Significant differences were also found by Carvalho et al. (2010), Freitas et al. (2007) and Teixeira et al. (2012) when evaluating morphoagronomic characteristics in Arabica coffee genotypes at 12 months after implantation. 
TABLE 1 - Cultivars of arabica coffee evaluated.

\begin{tabular}{ll}
\hline Cultivar & Main characteristics \\
\hline Catuaí Vermelho IAC 144 & $\begin{array}{l}\text { Low-size, susceptible to rust and nematodes, late ripening cycle, good } \\
\text { sensory quality, high vigor and high productivity. }\end{array}$ \\
\hline
\end{tabular}

Bourbon Amarelo IAC J10

Topázio MG 1190

MGS Epamig 1194

Catiguá MG2

MGS Catiguá 3

MGS Ametista

Pau Brasil MG1

MGS Paraíso 2

MGS Aranãs

Sarchimor MG 8840

IAC $125 \mathrm{RN}$
Medium to high size, susceptible to rust and nematodes, medium to early maturation cycle, excellent sensory quality, low vigor, medium productivity.

Low to medium size, susceptible to rust and nematodes, medium maturation cycle, good sensory quality, high vigor and high productivity.

Low-size, susceptible to rust and nematodes, medium ripeness cycle, good sensory quality, high vigor and high productivity.

Low-size, highly resistant to rust and susceptible to nematodes, medium maturation cycle, good sensory quality, high vigor and high productivity.

Low-size, highly resistant to rust and M. exigua, medium maturation cycle, good sensory quality, high vigor and high productivity.

Low-size, highly resistant to rust and susceptible to nematodes, medium to late ripening cycle, good sensory quality and high productivity.

Low-size, highly resistant to rust and susceptible to nematodes, medium maturation cycle, good sensory quality, medium vigor and high productivity. Low-size, resistant to rust and, nematodes, medium maturation cycle, good sensory quality and high productivity.

Low-size, resistant to rust and susceptible to nematodes, good sensory quality, high vigor and hight productivity.

Low-size, susceptible to rust and nematodes, good sensory quality and hight productivity.

Low-size, resistant to rust and two races of $M$. exigua, early maturation cycle, good sensory of drink, demanding in nutrition and water.
Other authors also found significant differences between arabica coffee genotypes in relation to the percentage of grains with sieve 16 and above (Carvalho et al., 2012; Nadalaleti et al., 2018), percentage of mocha-type grains and sensory analysis (NADALETI et al., 2018). On the other hand, Nadaleti et al. (2018) found a significant difference between genotypes for aspect of raw grains naturally processed, unlike the observed in the present work.

In Table 3 it can be observed that for plant height the cultivars were grouped in four distinct groups, so that the cultivar Bourbon Amarelo IAC J10 stands out with higher plant height, with 104.71 $\mathrm{cm}$ at 15 months of age, differing statistically from the others. This fact is justified, since it reflects an intrinsic characteristic of the evaluated cultivars, that is, the cultivar Bourbon Amarelo IAC J10 is the only evaluated cultivar of high size (Table 1).
The second group consisted of the cultivars MGS Epamig 1194, Ametista, MGS Aranãs, Topázio MG1190, MGS Catiguá 3 and Catiguá MG2, ranging from 76.21 to $70.17 \mathrm{~cm}$ in plant height. Freitas et al. (2007) when evaluating the growth increment in cultivars of low height in the period of 6 to 12 months, as well as Carvalho et al. (2010), when evaluating plant height at 12 months after planting, also verified a significant difference between the genotypes, so that, as in the present study, the cultivar Topázio MG 1190 exhibits higher growth than Catuaí Vermelho IAC 144, evidencing their genetic characteristics. However, according to Carvalho et al. (2010), the cultivar Pau Brasil MG1 presents higher growth than the cultivars Catiguá MG2 and the Catuaí Vermelho IAC 144, unlike this work, in which the cultivar Pau Brasil MG1 is inserted in the group of lower growth, with inferior performance to the cultivars previously cited (Table 3 ). 
TABLE 2 - Summary of Analysis of variance of the agronomic and sensory characters regarding the evaluation of cultivars of arabica coffee in Monte Carmelo, MG, in the 2017/18 agricultural year.

\begin{tabular}{|c|c|c|c|c|c|c|c|c|}
\hline \multirow{2}{*}{ Characteristic } & \multicolumn{3}{|c|}{ Cultivars } & \multicolumn{2}{|c|}{ Residue } & \multirow{2}{*}{ Mean } & \multirow{2}{*}{ CV (\%) } & \multirow{2}{*}{$\begin{array}{c}\text { Selective } \\
\text { Accuracy } \\
(\%)\end{array}$} \\
\hline & GL & QM & & GL & QM & & & \\
\hline Height & 11 & 506.93 & $*$ & 33 & 11.90 & 72,44 & 4.76 & 98.82 \\
\hline Dstem & 11 & 6.69 & $*$ & 33 & 2.02 & 21,18 & 6.71 & 83.53 \\
\hline Dcrown & 11 & 420.51 & $*$ & 33 & 30.99 & 103,24 & 5.39 & 96.24 \\
\hline NPB & 11 & 10.04 & $*$ & 33 & 1.32 & 26,08 & 4.40 & 93.21 \\
\hline Vigor & 11 & 2.46 & $*$ & 33 & 0.28 & 9,36 & 5.62 & 94.21 \\
\hline Prod & 11 & 40.06 & $*$ & 33 & 0.35 & 5,66 & 10.50 & 99.56 \\
\hline Sensory PNC & 11 & 13.66 & $*$ & 33 & 0.18 & 85,32 & 0.50 & 99.33 \\
\hline Sensory NC & 11 & 6.72 & $*$ & 33 & 0.26 & 84,64 & 0.60 & 98.08 \\
\hline Aspect PNC & 11 & 0.53 & $*$ & 11 & 0.12 & 4,58 & 7.60 & 87.83 \\
\hline Aspect NC & 11 & 0.58 & ns & 11 & 0.27 & 4,33 & 12.05 & 72.55 \\
\hline Sieve 16+ & 11 & 390.94 & $*$ & 11 & 8.87 & 79,23 & 3.76 & 98.86 \\
\hline Mocha & 11 & 29.87 & $*$ & 11 & 6.10 & 12,40 & 19.93 & 89.21 \\
\hline
\end{tabular}

*Significant at 5\% probability by the test F. Height: Height of the plant, $\mathrm{cm}$; Dstem: stem diameter at $10 \mathrm{~cm}$ from the ground, mm; Dcrown: crown diameter, cm; NPB: number of plagiotropic branches; Vigor: vegetative vigor, scale from 1 to 10; Prod: productivity bags ha ${ }^{-1}$; Sensory PNC: sensory analysis of wet processed coffee (pulped natural coffee); Sensory NC: sensoriy analysis of naturally processed coffee (natural coffee); Aspect PNC: aspect of raw grains wet processed, scale from 1 to 5; Aspect NC: aspect of the raw grains naturally processed, scale of 1 to 5; Sieve 16+: percentage of grains with sieve 16 and above in the sample; Mocha: percentage of mocha type grains in the sample.

This may be due to the fact that the cultivar Pau Brasil MG1 presents lower stability for the character plant height, more influenced by the effects of environment and genotypes $\mathrm{x}$ environments interaction.

According to Teixeira et al. (2013), evaluations of morphological characteristics and their correlation estimates are important for breeding programs, as they aid in the selection and early disposal of accesses. Previous studies have reported a high phenotypic correlation between plant height and grain yield in the first crop (Martinez et al., 2007) and the average of the first four crops (Carvalho et al., 2010). Severino et al. (2002), when evaluating the first three harvests of the Catimor group, found a low and negative correlation between these two characters, while the direct effect of plant height on grain yield was positive, indicating absence of cause and effect between these two characters, that is, productivity is not influenced by plant height.

The cultivars were separated into two statistically distinct groups for the stem diameter
(Dstem) character (Table 3). The highest values for this character were found for the cultivars Bourbon Amarelo IAC J10, MGS Paraíso 2; Sarchimor MG 8840, IAC 125 RN, Topazio MG 1190 and MGS Aranãs. Carvalho et al. (2010) and Bonomo et al. (2004) found a positive and significant correlation between this character and grain yield. However, Martinez et al. (2007) when evaluating coffee cultivars at different spacings, found that a high and negative direct effect of the stem diameter on productivity, indicating that the increase of the diameter of the stem competes with the productivity in the first harvest.

About the crown diameter (Dcrown) (Table 3 ), the cultivars were separated into three groups. In addition, there is a high coincidence between the genotypes with higher plant height and greater crown diameter, except for the cultivar Catuaí Vermelho 144, which is in the third group in relation to crown diameter, presenting the lowest value among the cultivars evaluated, but, in relation to plant height it is not found in the group of lower averages. This high coincidence 
can be explained by the high correlation between these two characters, reported by Carvalho et al. (2010) and Severino et al. (2002). However, opposite results were found by Freitas et al. (2007). According to these authors, the correlation between plant height and crown diameter is negative and significant, that is, the higher the height of the plant, the smaller the diameter of its crown, evidencing a mechanism of compensation between vertical and horizontal growth.

The crown diameter, which can also be evaluated as length of plagiotropic branches, presentshighcorrelation with grainyield, as reported by Carvalho et al. (2010), and is a good indicator for the early selection of genotypes. Freitas et al. (2007) also reported that the length of plagiotropic branches may be indicative of productivity, since it has a positive and significant correlation with the number of internodes of plagiotropic branches, that is, number of productive nodes, one of the main components of plant productivity. Severino et al. (2002) verified that the genotype correlation between crown diameter and yield of processed coffee was vitually nil. The grain yield was also not influenced by this character and not by the height of the plant. According to Miranda, Perecin and Pereira (2005), the characters that contribute most to the increase in productivity are the length of plagiotropic branches, plant height and stem diameter.

Taking into acount the number of plagiotropic branches, the cultivars evaluated were divided into three groups (Table 3 ). The first was composed just by the cultivar MGS Ametista, with an average of 29.58 branches per plant. The second group composed by five cultivars, presented averages of 26.25 to 27.75 branches per plant. The third group, with six cultivars, presented an average of 23.83 to 25.88 branches per plant. These values were higher than those found by Martinez et al. (2007) which, when evaluating cultivars of arabica coffee at 20 months after planting in the municipality of Ervália, MG, found a number of plagiotropic branches per plant varying from 22.4 to 26.0 .

TABLE 3 - Means of the morphoagronomic characters evaluated in 12 cultivars of Arabica coffee in the municipality of Monte Carmelo, MG in the 2017/18 harvest.

\begin{tabular}{|c|c|c|c|c|c|c|c|c|c|c|c|c|}
\hline Cultivar & Height & & Dstem & & Dcrown & & NPB & & Vigor & & Prod & \\
\hline $\begin{array}{l}\text { Catuaí } \\
\text { Vermelho IAC } \\
144\end{array}$ & 68.33 & $\mathrm{c}$ & 20.83 & $\mathrm{~b}$ & 89.33 & $\mathrm{c}$ & 26.67 & $\mathrm{~b}$ & 10.00 & $\mathrm{a}$ & 10.60 & $\mathrm{a}$ \\
\hline $\begin{array}{l}\text { Bourbon } \\
\text { Amarelo IAC } \\
\text { J10 }\end{array}$ & 104.71 & $\mathrm{a}$ & 23.57 & $\mathrm{a}$ & 129.50 & $\mathrm{a}$ & 25.88 & $\mathrm{c}$ & 9.00 & $\mathrm{~b}$ & 2.70 & $\mathrm{f}$ \\
\hline $\begin{array}{l}\text { Topázio MG } \\
1190\end{array}$ & 72.96 & $\mathrm{~b}$ & 21.56 & $\mathrm{a}$ & 102.92 & $\mathrm{~b}$ & 26.71 & $\mathrm{~b}$ & 9.88 & $\mathrm{a}$ & 8.20 & $\mathrm{c}$ \\
\hline $\begin{array}{l}\text { MGS Epamig } \\
1194\end{array}$ & 76.21 & $\mathrm{~b}$ & 20.50 & $\mathrm{~b}$ & 110.00 & $\mathrm{~b}$ & 24.67 & $\mathrm{c}$ & 9.75 & $\mathrm{a}$ & 9.40 & $\mathrm{~b}$ \\
\hline Catiguá MG2 & 70.17 & $\mathrm{~b}$ & 18.78 & $\mathrm{~b}$ & 102.83 & $\mathrm{~b}$ & 24.38 & $\mathrm{c}$ & 8.25 & $\mathrm{c}$ & 1.90 & $\mathrm{f}$ \\
\hline $\begin{array}{l}\text { MGS Catiguá } \\
3\end{array}$ & 72.21 & $\mathrm{~b}$ & 20.66 & $\mathrm{~b}$ & 105.67 & $\mathrm{~b}$ & 25.38 & $\mathrm{c}$ & 9.75 & $\mathrm{a}$ & 6.30 & $\mathrm{~d}$ \\
\hline MGS Ametista & 74.88 & $\mathrm{~b}$ & 20.68 & $\mathrm{~b}$ & 107.25 & $\mathrm{~b}$ & 29.58 & $\mathrm{a}$ & 10.00 & $\mathrm{a}$ & 3.70 & $\mathrm{e}$ \\
\hline $\begin{array}{l}\text { Pau Brasil } \\
\text { MG1 }\end{array}$ & 63.71 & d & 19.67 & $\mathrm{~b}$ & 99.58 & $\mathrm{~b}$ & 26.25 & $\mathrm{~b}$ & 9.50 & $\mathrm{a}$ & 2.20 & $\mathrm{f}$ \\
\hline MGS Paraíso 2 & 67.50 & $\mathrm{c}$ & 22.68 & $\mathrm{a}$ & 101.42 & $\mathrm{~b}$ & 27.75 & $\mathrm{~b}$ & 10.00 & $\mathrm{a}$ & 6.80 & $\mathrm{~d}$ \\
\hline MGS Aranãs & 74.08 & $\mathrm{~b}$ & 21.43 & $\mathrm{a}$ & 103.00 & $\mathrm{~b}$ & 26.75 & $\mathrm{~b}$ & 10.00 & $\mathrm{a}$ & 9.40 & $\mathrm{~b}$ \\
\hline $\begin{array}{l}\text { Sarchimor MG } \\
8840\end{array}$ & 61.58 & $\mathrm{~d}$ & 22.11 & $\mathrm{a}$ & 95.58 & $\mathrm{c}$ & 23.83 & $\mathrm{c}$ & 7.88 & $\mathrm{c}$ & 3.00 & $\mathrm{e}$ \\
\hline IAC $125 \mathrm{RN}$ & 63.00 & $\mathrm{~d}$ & 21.67 & $\mathrm{a}$ & 91.83 & $\mathrm{c}$ & 25.17 & $\mathrm{c}$ & 8.38 & $\mathrm{c}$ & 3.70 & $\mathrm{e}$ \\
\hline
\end{tabular}

Means followed by the same letter in the columns belong to the same group by the Scott-Knott test at $5 \%$ probability. Height: Height of the plant, $\mathrm{cm}$; Dstem: stem diameter at $10 \mathrm{~cm}$ from the ground, mm; Dcrown: crown diameter, cm; NPB: number of plagiotropic branches; Vigor: vegetative vigor, scale from 1 to 10; Prod: productivity bags ha-1. 
The highest development of the cultivars evaluated in the present work in comparison to the cultivars evaluated by Martinez et al. (2007), although five months younger, may be due not only to the genotypes, but also to the environmental conditions, since the evaluated plants in Monte Carmelo, $\mathrm{MG}$ are in an irrigated cultivation system. Assis et al. (2014) when evaluating the effect of irrigation on plant height, stem diameter and number of plagiotropic branches of the Rubi MG 1192 cultivar, observed that irrigation had a positive effect in these traits when compared to plants submitted to the dryland condition. According to Carvalho et al. (2010), the number of plagiotropic branches has a high correlation with productivity.

The vegetative vigor is related to the adaptability of the cultivars under different environmental conditions (CARVALHO et al., 2012; SEVERINO et al., 2002). Table 3 presents high vigor scores for the cultivars evaluated, ranging from 7.88 to 8.38 for the group with lower mean values, but still presenting good grades. In the group with higher averages, the cultivars MGS Ametista, MGS Paraíso 2, MGS Aranãs and Catuaí Vermelho IAC 144 achieve the maximum score for vigor in the scale proposed by Carvalho, Monaco and Fazuoli (1979). On this scale note 10 represents extremely vigorous, leafy plants with high growth of productive branches. The cultivars Topázio MG 1190, MGS Epamig 1194, MGS Catiguá 3 and Pau Brasil MG 1 are also statistically inserted in the first group.

In Table 3 it can be observed that the highest productivity values obtained for the cultivars included in the first four groups by the Scott-Knott test coincide with the higher values of vigor. These results corroborate those found by several authors regarding the relationship between vigor and productivity. Severino et al. (2002), when evaluating the effect of agronomic traits on grain yield in arabica coffee, reported the highest positive and significant correlations between vigor and grain yield in accumulated data for three years of production. This is a good criterion for evaluating the productive potential. Teixeira et al. (2013) stated that vigor, along with length of the 1 st plagiotropic branch, stem diameter and number of nodes of the 1st plagiotropic branch, are the main characteristics of greater importance and considered sufficient for the distinction of genotypes in arabica coffee still in youth stadium. Teixeira et al. (2012) also found a high correlation between grain yield and vegetative vigor, length of the first plagiotropic branch, width of leaves of the fourth pair of leaves and number of nodes of the first plagiotropic branch, that is, plants that at 12 month age present greater vigor and long first plagiotropic branch with large numbers of nodes tend to be more productive. In addition to high correlation, Severino et al. (2002) and Teixeira et al. (2013) observed a high positive direct effect of vigor on grain yield through path analysis. This explains why the vegetative vigor is one of the most used characters for the estimation of the productive capacity of coffee trees (CARVALHO et al., 2010; SEVERINO et al., 2002; TEIXEIRA et al., 2013).

In the present work, estimates of correlations between characters were not obtained, since, according to several authors, the effect of genotype $x$ environment interaction may influence the phenotypic expression of these associations, mainly of characters controlled by a large number of genes, such as productivity. In this way there is a great change in the magnitude and direction of the estimates depending on the local conditions where the genotypes are evaluated. Therefore, in order to obtain valid estimates of correlation, which can be extrapolated to different situations and thus provide gain through indirect selection, it is necessary to carry out these studies considering several locations and agricultural years (AZEVEDO FILHO et al., 1998; MONTEVERDE; 1984; PEREIRA, 2017).

With regard to productivity at 18 months, in Table 3 are presenting values ranging from 2.7 to 10.6 coffee bags processed per hectare. The cultivars were divided into six groups. The first one is just of the cultivar Catuaí Vermelho IAC 144 , with an average productivity of 10.6 bags ha $^{-1}$. Moura et al. (2000) evaluated the first crop of 20 lines of coffee cultivars in Belizário, Minas Gerais State, Brazil, and also observed that Catuaí Vermelho 144 was among the most productive with 29.60 bags ha $^{-1}$. The same result was observed by Carvalho et al. (2010) when evaluating 25 cultivars for productivity 30 months after the implantation of the crop in the municipalities of Patrocinio, Campos Altos and Santo Antônio do Amparo, MG (68.7, 21.43 and 15.82 bags ha ${ }^{-1}$, respectively), evidencing the stability of this cultivar in different conditions.

In the second group, the cultivars MGS EPAMIG 1194 and MGS Aranãs, both with average productivities of $9.4 \mathrm{bags} \mathrm{ha}^{-1}$, stand out. 
The cultivar Topázio MG 1190 appears alone in the third group, with a yield of 8.2 bags ha $^{-1}$. Moura et al. (2000) also verified intermediate productivity for this cultivar, with average productivity of 21.73 bags ha ${ }^{-1}$. Carvalho et al. (2010) observed that this cultivar, 30 months after planting, appeared among the worst ones in productivity in the municipality of Santo Antônio do Amparo (8.25 $\left.\mathrm{bags} \mathrm{ha}^{-1}\right)$, but it presented intermediate performance in Patrocínio (34.01 bags ha-1) and medium to high in Campos Altos (18.36 bags ha-1), considering the average values of the cultivars for each site.

The cultivars Catiguá MG2, Bourbon Amarelo IAC J10 and Pau Brasil MG1 presented lower productivity results in the present work. Similar results were obtained by Carvalho et al. (2010) for the cultivar Catiguá MG2 in Campos Altos and Santo Antônio do Amparo. However, contrary results were found for the cultivar Pau Brasil MG 1, which presented intermediate productivity in Patrocínio and high in Campos Altos.

In addition to the good productive performance, it is sought, in the coffee breeding programs, genotypes that present other favorable characteristics, such as higher percentage of grains classified in higher sieves and sensory quality (FERREIRA et al, 2005) once exporters prefer larger grains, because this way they are automatically eliminating defects (CUSTÓDIO; GOMES; LIMA, 2007).

After processing, the coffee is characterized according to norms and grading standards of raw grain as to type, size, shape and beverage (CUSTÓDIO; GOMES; LIMA, 2007). The averages of the cultivars referring to the characters related to grain quality are presented in Table 4 .

According to the Brazilian Association of the Coffee Industry (ABIC), not only the processing or care in roasting and grinding or a carefully controlled blend make the coffee beverage quality. The genetic origin of the beans has as much influence on the final result as all the other care involved in the production, from the coffee plant to the cup of the consumer (MALTA et al., 2002; MARTINEZ et al., 2018; MARTINEZ, ZAPATA-ZAPATA, DURANGO-RESTREPO, 2018). This fact can be observed in Table 4, where the sensory analysis separated the coffee cultivars into five statistically distinct groups for wet processed coffees and in four groups for naturally processed coffee. Several authors also found sensory diversity among cultivars in Southern and Southeastern Brasil, including modern (derived from Hibrido de Timor) and traditional cultivars as superior (PEREIRA et al., 2010; KITZBERGER et al., 2011CHALFOUN et al., 2013; SCHOLZ et al., 2013; SOBREIRA et al., 2016).

TABLE 4 - Means of the characters related to grain quality evaluated in 12 cultivars of arabica coffee in the municipality of Monte Carmelo, MG in the 2017/18 harvest.

\begin{tabular}{lcccccccccccc}
\hline Cultivar & \multicolumn{2}{c}{ Sensory PNC } & Sensory & NC Aspect NC & $\begin{array}{c}\text { Aspect } \\
\text { PNC }\end{array}$ & Sieve 16+ & Mocha \\
\hline Catuaí Vermelho IAC 144 & 85.83 & $\mathrm{c}$ & 87.00 & $\mathrm{a}$ & 4,00 & $\mathrm{a}$ & 4.00 & $\mathrm{~b}$ & 86.50 & $\mathrm{a}$ & 10.75 & $\mathrm{a}$ \\
Bourbon Amarelo IAC J10 & 90.00 & $\mathrm{a}$ & 86.17 & $\mathrm{~b}$ & 4.50 & $\mathrm{a}$ & 5.00 & $\mathrm{a}$ & 88.75 & $\mathrm{a}$ & 9.50 & $\mathrm{a}$ \\
Topázio MG 1190 & 84.33 & $\mathrm{~d}$ & 84.50 & $\mathrm{c}$ & 4.00 & $\mathrm{a}$ & 4.50 & $\mathrm{a}$ & 75.00 & $\mathrm{~b}$ & 16.25 & $\mathrm{a}$ \\
MGS Epamig 1194 & 84.18 & $\mathrm{~d}$ & 85.83 & $\mathrm{~b}$ & 4.50 & $\mathrm{a}$ & 4.50 & $\mathrm{a}$ & 84.25 & $\mathrm{a}$ & 13.00 & $\mathrm{a}$ \\
Catiguá MG2 & 83.50 & $\mathrm{e}$ & 84.50 & $\mathrm{c}$ & 4.00 & $\mathrm{a}$ & 4.50 & $\mathrm{a}$ & 58.00 & $\mathrm{c}$ & 13.50 & $\mathrm{a}$ \\
MGS Catiguá 3 & 83.33 & $\mathrm{e}$ & 82.83 & $\mathrm{~d}$ & 3.50 & $\mathrm{a}$ & 3.50 & $\mathrm{~b}$ & 78.00 & $\mathrm{~b}$ & 17.75 & $\mathrm{a}$ \\
MGS Ametista & 84.18 & $\mathrm{~d}$ & 82.83 & $\mathrm{~d}$ & 5.00 & $\mathrm{a}$ & 5.00 & $\mathrm{a}$ & 81.25 & $\mathrm{~b}$ & 10.75 & $\mathrm{a}$ \\
Pau Brasil MG1 & 85.68 & $\mathrm{c}$ & 84.17 & $\mathrm{c}$ & 4.50 & $\mathrm{a}$ & 5.00 & $\mathrm{a}$ & 45.50 & $\mathrm{~d}$ & 18.25 & $\mathrm{a}$ \\
MGS Paraíso 2 & 87.18 & $\mathrm{~b}$ & 84.17 & $\mathrm{c}$ & 3.50 & $\mathrm{a}$ & 4.00 & $\mathrm{~b}$ & 86.50 & $\mathrm{a}$ & 11.50 & $\mathrm{a}$ \\
MGS Aranãs & 85.33 & $\mathrm{c}$ & 85.67 & $\mathrm{~b}$ & 5.00 & $\mathrm{a}$ & 5.00 & $\mathrm{a}$ & 91.25 & $\mathrm{a}$ & 7.00 & $\mathrm{a}$ \\
Sarchimor MG 8840 & 84.50 & $\mathrm{~d}$ & 84.33 & $\mathrm{c}$ & 5.00 & $\mathrm{a}$ & 5.00 & $\mathrm{a}$ & 91.25 & $\mathrm{a}$ & 6.25 & $\mathrm{a}$ \\
IAC 125 RN & 85.83 & $\mathrm{c}$ & 83.67 & $\mathrm{c}$ & 4.50 & $\mathrm{a}$ & 5.00 & $\mathrm{a}$ & 84.50 & $\mathrm{a}$ & 14.25 & $\mathrm{a}$
\end{tabular}

Means followed by the same letter in the columns belong to the same group by the Scott-Knott test at $5 \%$ probability. Sensory PNC: sensory analysis of wet processed coffee; Sensory NC: sensoriy analysis of naturally processed coffee; Aspect PNC: aspect of raw grains wet processed, scale from 1 to 5; Aspect NC: aspect of the raw grains naturally processed, scale of 1 to 5; Sieve 16+: percentage of grains with sieve 16 and above in the sample; Mocha: percentage of mocha type grains in the sample. 
In wet processing, the Bourbon Amarelo IAC J10 cultivar was the only component in the group with the highest mean, presenting 90 points according to the SCA protocol. Cultivar Bourbon has world-renowned intrinsic qualities dui to its sensory characreristics. It is usef for the production of specialty coffees in different regions of the world (FIGUEIREDO et al., 2018; SOBREIRA et al., 2015a; Sobreira et al., 2015b). In the natural processing, this cultivar is in the second best group, along with the cultivars MGS Epamig 1194 and MGS Aranãs, with scores varying from 85.67 to 86.17 . Still in this processing, the cultivar that stood out as only component of the best group was Catuaí Vermelho IAC 144, with 87 points.

In general, it was observed that all the cultivars present good sensory quality, both in wet processing, with notes from 83.33 to 90 points, as well as in natural processing, ranging from 82.83 to 87 points. The sensory analysis according to the SCA methodology considers as special coffees those with scores equal to or above 80 points, that is, all cultivars evaluated in the two forms of processing are in this category. In addition, coffees with a score equal to or above 85 points are rated as excellent. In the present work, the cultivars MGS Epamig 1194 naturally processed, MGS Paraíso 2, IAC 125 RN and Pau Brasil MG1 wet processed and Catuaí Vermelho IAC 144, Bourbon Amarelo IAC J10 and Aranãs in the two types of processing, are classified as excellent.

None of the cultivars, in both processes, presented sensory defect, so that the five cups per plot were considered clean, with presence of sweetness and uniformity among them, guaranteeing a maximum score (10 points) for these attributes. For the other seven attributes, no cultivar presented a score lower than 7.50 (Figures 1 and 2), which reflects in the high final score reached, as described in Table 4.

Figures 1 and 2 present the averages of the attributes for each cultivar. The cultivars in general presented a good balance between the attributes, especially considering the wet processing (Figure 1), in which the cultivar Bourbon Amarelo IAC J10 presents superiority of all the attributes on the other cultivars, except for the attribute body, in that it is equal to the cultivar MGS Paraíso 2. In the natural processing (Figure 2), the cultivar Catuaí Vermelho IAC 144 is superior to the others, considering the attributes Fragrance, Flavor and Over all. In the other evaluated attributes this cultivar is equal to the other cultivars, and inferior just to the cultivar Bourbon Amarelo IAC J10 in the Acidity item. According to Bártholo and Guimarães (1997), the classification of coffee regarding the type refers to its appearance and quantity of defects. The aspect is influenced by the coloring of the grains. Nadaleti et al. (2018) considers, in the assessment of appearance, besides color, grain uniformity and the presence or absence of adhered espermoderm.

In Table 4 can be observed that the aspect presented values of 3.5 to 5 for the two types of processing, on a scale of 1 to 5 . However, no significant difference was detected by the $\mathrm{F}$ test among cultivars for the samples naturally processed (Table 2). The wet-processed samples were separated into two groups by the Scott-Knott test at $5 \%$ probability. The group with the lowest values consisted for only three cultivars: Catuaí Vermelho IAC 144, MGS Paraíso 2 and MGS Catiguá 3. Still, these cultivars exhibited good appearance, with characteristics equal to or greater than average-looking grain, greenish coloration (typical of natural coffees processed dry) and light presence of adhered espermoderm, according to the scale proposed by Nadaleti et al. (2018).

Regarding the percentage of mocha-type grains, a significant difference among cultivars was observed in the F-test at 5\% probability. However, according to Table 4, it was verified that, by Scott-Knott's test, there was no grouping of cultivars in different groups.

Although not considered a defect in the physical classification of coffees, mocha type beans are considered defective from the point of view of crop breeding, since the formation of only one seed in the fruit leads to a lower yield of processed coffee.

According to Paiva et al. (2010) and Carvalho et al. (2013), in the production of certified coffee seeds the maximum tolerance of mocha seed is $12 \%$. In the present study, the cultivars Pau Brasil MG1, MGS Catiguá 3, Topázio MG 1190, IAC 125 RN, Catiguá MG 2 and MGS Epamig 1194 presented a percentage of mocha above this limit. Therefore, further studies on these cultivars are necessary, considering the next harvests, since, according to Pezzopane et al. (2007), the occurrence of this type of grain may be associated with adverse environmental factors, such as high temperatures in flowering or early fruiting.

About the percentage of grains with sieve 16 and above in the sample, genetic difference was observed among the cultivars evaluated (Table 2). 

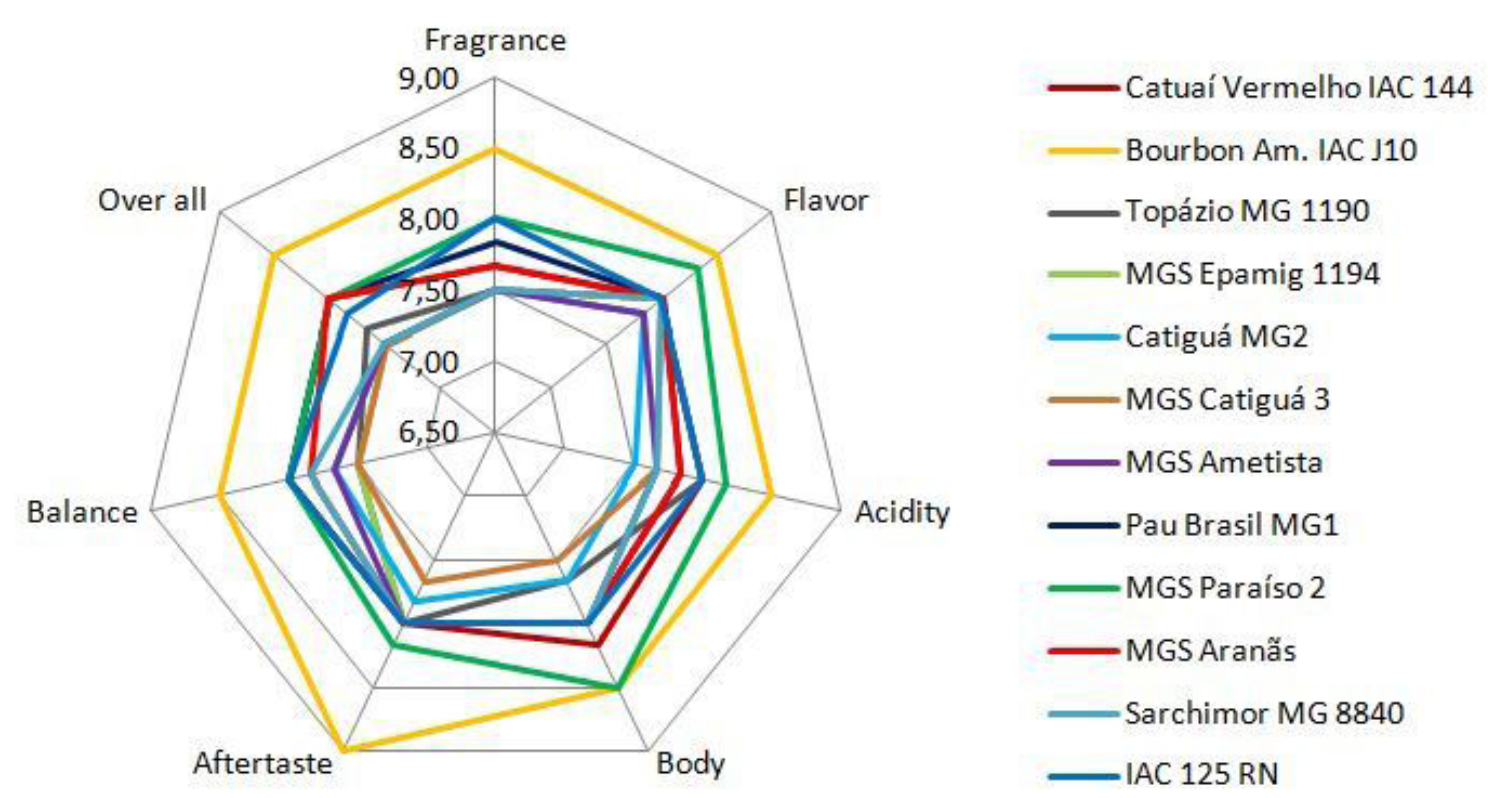

FIGURE 1 - Sensogram based on averages of the sensory attributes of cultivars evaluated in wet processing.

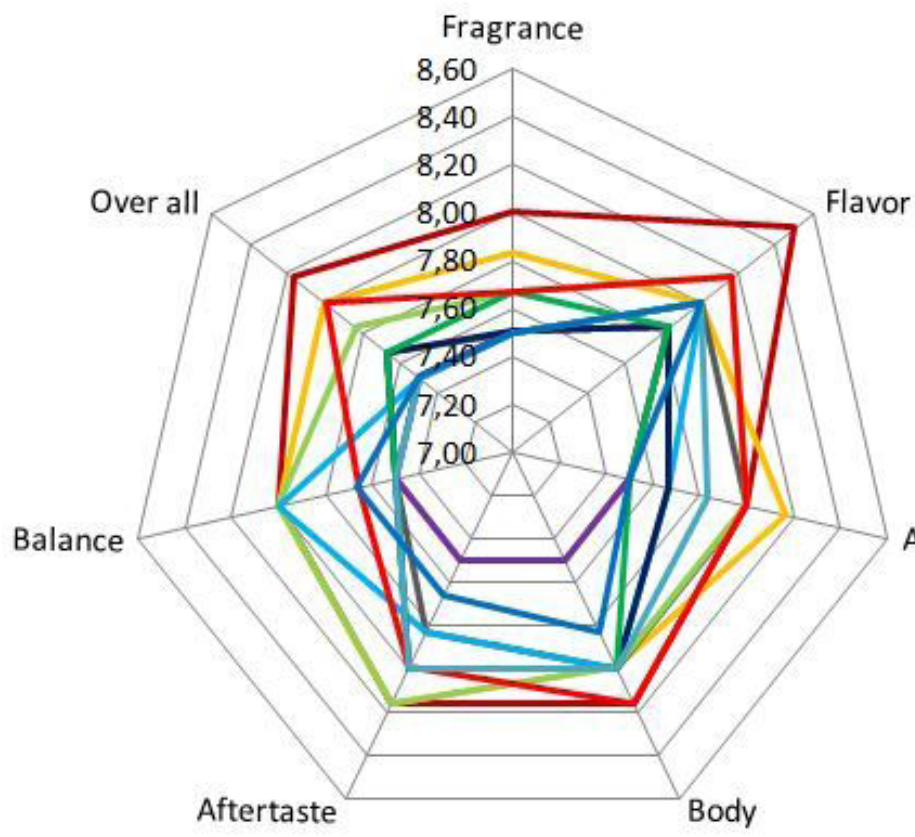

- Catuaí Vermelho IAC 144

Bourbon Am. IAC J10

Topázio MG 1190

MGS Epamig 1194

Catiguá MG2

MGS Catiguá 3

MGS Ametista

Acidity

Pau Brasil MG1

MGS Paraíso 2

MGS Aranãs

Sarchimor MG 8840

IAC 125 RN

FIGURE 2 - Sensogram based on averages of the sensory attributes of cultivars evaluated in natural processing. 
In Table 4 it can be verified that the cultivars were grouped in four groups by the Scott-Knott test. In general, all cultivars presented a high percentage of sieve grains 16 and above, with more than $50 \%$, reaching up to $91.25 \%$ for cultivars MGS Aranãs and Sarchimor MG 8840. Only the cultivar Pau Brasil 1 presented a lower value, with $45.5 \%$ and was the only one to compose the worst group in this study. Nadaleti et al. (2018) and Carvalho et al. (2012) found, in general, similar percentages of sieve grains 16 and higher when evaluating commercial arabica coffee genotypes and cultivars. However, in studies by Carvalho et al. (2012), the cultivar Pau Brasil MG1, with worse average in the present work, is included in the best group in this respect in four growing environments. These authors, on the other hand, found lower results $(64.2 \%)$ than the present work for the cultivar Bourbon Amarelo IAC J10, which presented $88.75 \%$ of grains with 16 and above sieves, ranking in the first group together with the cultivars MGS Aranãs, Sarchimor MG 8840, MGS Paraíso 2, Catuaí Vermelho IAC 144, IAC 125 RN and MGS Epamig 1194. The cultivar Catiguá MG 2 presented similar performance, considering both, the present work (58\%) and other carried out by Carvalho et al. (2012) in the average of four sites $(54.3 \%)$. A high percentage of grains with high sieve have a higher potential to add value in coffee commercialization, besides indicating good conditions of nutritional and sanitary management in all stages of fruit formation (NADALETI et al., 2018).

\section{CONCLUSIONS}

There is genetic variability among the cultivars for the vegetative and sensory characters.

The cultivars Catuaí Vermelho IAC 144 and MGS Aranãs belong to the most productive groups at 18 months after planting, with a high percentage of sieve 16 and above and low for mocha types.

For the sensoriy quality, all the cultivars presented as special, with emphasis on the cultivar Bourbon Amarelo IAC J10 in wet processing and Catuaí Vermelho IAC 144 in natural processing.

\section{ACKNOWLEDGMENTS}

The authors are grateful to EPAMIG for the availability of the infrastructure and equipment and to the promotion agencies CNPq, FAPEMIG and Consórcio Pesquisa Café for financial support.

\section{REFERENCES}

ASSIS, G. A. de et al. Correlação entre crescimento e produtividade do cafeeiro em função do regime hídrico e densidade de plantio. Bioscience Journal, Uberlândia, v. 30, n. 3, p. 666-676, maio/jun. 2014.

AZEVEDO FILHO, J. A. de; et al. Estimativas de parâmetros genéticos de populações de soja em solos contrastantes na saturação de alumínio. Bragantia, Campinas, v. 57, n. 2, p. 227-239, 1998.

BÁRThOlO, G. F.; GUIMARÃES, P.T.G. Cuidados na colheita e preparo do café. Informe Agropecuário, Belo Horizonte, v. 18, n. 187, p.33-42, 1997.

BONOMO, P. et al. Avaliação de progênies obtidas de cruzamentos de descendentes do híbrido de Timor com as cultivares Catuaí Vermelho e Catuaí Amarelo. Bragantia, v. 63, n. 2 p. 207-219, 2004.

BOTELHO, C. E. et al. Adaptabilidade e estabilidade fenotípica de cultivares de café arábica em Minas Gerais. Pesquisa Agropecuária Brasileira, Brasília, v. 45, n. 12, p. 1404-1411, dez. 2010.

CARGNIN, A. et al. Interação entre genótipos e ambientes e implicações em ganhos com seleção em trigo. Pesquisa Agropecuária Brasileira, v. 41, n. 6, p. 987-993, jun. 2006.

CARVALHO, A. M. D. et al. Correlação entre crescimento e produtividade de cultivares de café em diferentes regiões de Minas Gerais, Brasil. Pesquisa Agropecuária Brasileira, Brasília, v. 45, n. 3, p. 269275, mar. 2010.

CARVALHO, A. M. et al. Desempenho agronômico de cultivares de café resistentes à ferrugem no estado de Minas Gerais. Bragantia, Campinas, v. 71, n. 4, p. 481487, dez. 2012.

CARVALHO, A.; MONACO, L. C.; FAZUOLI, L. C. Melhoramento do cafeeiro XL: Estudos de progênies e híbridos de café Catuaí. Bragantia, Campinas, v. 38, n. 22, p. 202-216, nov. 1979.

CARVALHO, G. R. et al. Comportamento de progênies F4 de cafeeiros arábica, antes e após a poda tipo esqueletamento. Coffee Science, Lavras, v. 8, n. 1, p. 33-42, jan./mar. 2013.

CHALFOUN, S. M. et al. Sensorial characteristics of coffee (Coffea arabica L.) varieties in the Alto Paranaíba Region. Coffee Science, Lavras, v. 8, p. 4352, 2013. 
CONAB - Companhia Nacional de Abastecimento. Acompanhamento da Safra Brasileira: Café. (2018). Disponível em: <https://www.conab.gov.br/index.php/ info-agro/safras/cafe>. Acesso em: 02 fev. 2019.

CONSÓRCIO PESQUISA CAFÉ. Consórcio Pesquisa Café destaca as cultivares do Instituto Agronômico de Campinas que mudaram a cafeicultura brasileira nos últimos cinquenta anos. (2012). Disponível em: $<$ http://www.consorciopesquisacafe.com.br/index. $\mathrm{php} /$ imprensa/noticias/258-consorcio-pesquisa-cafedestaca-as-cultivares-do-instituto-agronomico-decampinas-que-mudaram-a-cafeicultura-brasileira-nosultimos-cinquenta-anos>.Acesso em: 03 fev. 2019.

COOXUPÉ - Cooperativa Regional de Cafeicultores em Guaxupé LTDA (Guaxupé) (Org.). Dados históricos: Monte Carmelo. 2017/2018. Disponível em: <http://sismet.cooxupe.com.br:9000/dados/ estacao/pesquisarDados/>. Acesso em: 02 fev. 2019.

CRUZ, C. D. GENES - a software package for analysis in experimental statistics and quantitative genetics. Acta Scientiarum Agronomy, Maringá, v.35, n.3, p.271-276, set. 2013.

CRUZ, C. D.; REGAZZI, A. J.; CARNEIRO, P.C. S. Divergência genética. In: Modelos biométricos aplicados ao melhoramento genético. Viçosa, MG: UFV, 2004. v. 1, p. 377-413.

CUSTÓDIO, A. A. P.; GOMES, N. M.; LIMA, L. A. Efeito da irrigação sobre a classificação do café. Engenharia Agrícola, Jaboticabal, v. 27, n. 3, p. 691701, set./dez. 2007.

FERNANDES, et al. A moderna cafeicultura dos cerrados brasileiros. Pesquisa Agropecuária Tropical, Goiânia, v. 42, n. 2, p. 231-240, abr./jun. 2012.

FERREIRA, A. et al. Seleção simultânea de Coffea canephora por meio da combinação de análise de fatores e índices de seleção. Pesquisa Agropecuária Brasileira, Brasília, v.40, n. 12, p.1189-1195, dez. 2005.

FIGUEIREDO, L. P. et al. Sensoru analysis and chemical composition of 'Bourbon' coffees cultivated in different environments. Coffee Science, Lavras, v. 13, n. 1, p. 122-131, jan./mar. 2018.

FREITAS, Z. M. T. S. et al. Avaliação de caracteres quantitativos relacionados com o crescimento vegetativo entre cultivares de café arábica de porte baixo. Bragantia, Campinas, v. 66, n. 2, p. 267-275, abr. 2007.
KITZBERGER, C. S. G. et al. Caracterização sensorial de cafés arábica de diferentes cultivares produzidos nas mesmas condições edafoclimáticas. Brazilian Journal of Food Technology, Campinas, v. 14, p. 39-48, 2011.

MALTA, M. R.; SANTOS, M. L.; SILVA, F. A. M. Qualidade de grãos de diferentes cultivares de cafeeiro (Coffea arabica L.). Acta Scientiarum Agronomy, Maringá, v. 24, n. 5, p. 1385-1390, 2002.

MAPA-Ministério da Agricultura, Pecuária e Abastecimento. Registro nacional de Cultivares RNC. Disponível em: <http://sistemas.agricultura. gov.br/snpc/cultivarweb/cultivares_registradas.php $>$. Acesso em: 03 fev. 2019.

MARTINEZ, A. E. P; ZAPATA-ZAPATA, A. D.; DURANGO-RESTREPO, D. L. Performance of different fermentation methods and the effect on coffee quality (Coffea arábica L.). Coffee Science, Lavras, v. 13 , n. 4, p. 465-476, oct./dec. 2018.

MARTINEZ, H. E. P. et al. Crescimento vegetativo de cultivares de café (Coffea arabica L.) e sua correlação com a produção em espaçamentos adensados. Acta Scientiarum Agronomy, Maringá, v. 29, n. 4, p. 481489, out. 2007.

MARTINEZ, H. E. P. et al. Production, chemical composition, and quality of Arabic coffee subjected to copper doses. Pesquisa Agropecuária Brasileira, Brasília, v. 53, n. 4, p. 443-452, Apr. 2018.

MIRANDA, J. M.; PERECIN, D.; PEREIRA, A. A. Produtividadee resistência à ferrugem do cafeeiro (Hemileia vastatrix Berk. Et. Br.) de progênies F5 de Catuaí Amarelo com o Híbrido de Timor. Ciência e Agrotecnologia, v. 29, n. 6, p. 1195-1200, nov./dez. 2005.

MONTEVERDE, E. Correlaciones fenotípicas y genotípicas entre rendimiento, proteina, aceite y otras características em soya (Glycine max). Revista de la Facultad de Agronomia, Macaray, v. 13, n. 1, p. 183214, 1984.

MOURA, W. M. et al. Ensaio regional de linhagens de café arábica. In: SIMPÓSIO DE PESQUISA DOS CAFÉS DO BRASIL. Poços de Caldas, MG. Resumos... Brasília: Embrapa/Minasplan,v. 2, p. 484487, 2000.

NACIF, A.P. Fenologia e produtividade do cafeeiro (Coffea arabica L.) cv. Catuaí, sob diferentes densidades de plantio e dosesde fertilizantes no Cerrado de Patrocínio - MG. 1997. Tese (Doutorado em Fitotecnia) - Universidade Federal de Viçosa, Viçosa, 1997. 
NADALETI, D. H. S. et al. Productivity and sensory quality of arabica coffee in response to pruning type "esqueletamento". Journal of Agricultural Science, v. 10, n. 6, p. 207-216, maio 2018.

ORTEGA, A. C.; JESUS, C. M. Café do Cerrado: certificação de origem, nova sociologia econômica e desenvolvimento territorial rural. I Seminário Nacional de Sociologia Econômica, Florianópolis. Anais... Florianópolis: Universidade Federal de Santa Catarina, 2009.

ORTEGA, A. C. JESUS, C. M. Território, certificação de procedência e a busca da singularidade: o caso do café do Cerrado. Política e Sociedade, Florianópolis, v. 10 , n. 19 , out. 2011.

PAIVA, R. N. et al. Comportamento agronômico de progênies de cafeeiro (Coffea arabica L.) em Varginha - MG. Coffee Science, Lavras, v. 5, n. 1, p. 49-58, jan./ abr. 2010.

PEREIRA, D. R. Interação genótipos x ambientes e implicações na associação entre caracteres em soja. Dissertação (Mestrado em Genética e Melhoramento de Plantas) - Universidade Federal de Lavras, Lavras, 2017.

PEREIRA, M. C. et al. Multivariate analysis of sensory caracteristics of coffee grains (Coffea arábica L.) in the region of upper Paranaíba. Acta Scientiarum Agronomy, Maringá, v. 32, p. 635-641, 2010.

PEZZOPANE, J. R. M. et al. Avaliações fenológicas e agronômicas em café arábica cultivado a pleno sol e consorciado com banana prata anã. Bragantia, Campinas,v. 66, n. 4, p. 701-709, 2007.

REVISTA CAFEICULTURA. $\mathbf{9 0 \%}$ das cultivares de café arábica plantadas no Brasil são desenvolvidas pelo IAC. (2015). Disponível em: <http:// revistacafeicultura.com.br/?mat=59994>. Acesso em 03 fev. 2019.

RESENDE, M. D. V.; DUARTE, J. B. Precisão e controle de qualidade em experimentos de avaliação de cultivares. Pesquisa Agropecuária Tropical, v.3, n.37, p.182-194, 2007.
RIBEIRO, B. B. et al. Sensory Analysis of coffee dried with and without stirring. Coffee Science, Lavras, v. 13, n.4, p. 455-464, oct./dec. 2018.

SAES, M. S. M.; JAYO, M. Caccer: coordenando ações para a valorização do Café do Cerrado. VII Seminário Internacional PENSA de Agribusiness, São Paulo. Anais... São Paulo: PENSA-FIA-USP, 1997.

SCHOLZ, M. B. S. et al. Atributos sensoriais e características físico-químicas de bebida de cultivares de café do IAPAR. Coffee Science, Lavras, v. 8, p. 6-16, 2013.

SCOTT, A.; KNOTT, M. Cluster-analysis method for grouping means in analysis of variance. Biometrics, Washington D. C., v.30, n.3, p. 507-512, set. 1974.

SEVERINO, L. S. et al. Associações da produtividade com outras características agronômicas de café (Coffea arabica L. "Catimor"). Acta Scientiarum Agronomy, Maringá, v. 24, n. 5, p. 1467-1471, dez.2002.

SOBREIRA, F. M. et al. Divergence among arábica coffee genotypes for sensory quality. Australian Journal of Crop Science, v. 10, n. 10, p. 1142-1448, 2016.

SOBREIRA, F. M. et at. Potential of Híbrido de Timor germoplam and its derived progenies for coffee quality improvement. Australian Journal of Crop Science, v. 9, n. 4, p. 289-295, 2015a.

SOBREIRA, F. M. et at. Sensory quality of arábica coffee (Coffee arabica) genealogic groups using the sensogram and content analysis. Australian Journal of Crop Science, v. 9, n. 6, p. 486-493, 2015 b.

TEIXEIRA, A. L. et al. Análise de componentes principais em caracteres morfológicos de café arábica em estádio juvenil. Coffee Science, Lavras, v. 8, n. 2, p. 205-210, abr./jun. 2013.

TEIXEIRA, A. L. et al. Seleção precoce para produção de grãos em café arábica pela avaliação de caracteres morfológicos. Pesquisa Agropecuária Brasileira, Brasília, v.47, n.8, p.1110-1117, ago. 2012 